\title{
Effect of Season on UV Absorbing Property of Syzygium cumini L. Leaves
}

\author{
Prasenjit Mitra ${ }^{1}$, Prasanta Kumar Mitra ${ }^{2 *}$ and Tanaya Ghosh ${ }^{2}$ \\ ${ }^{1}$ Department of Biochemistry, All India Institute of Medical Sciences (AIIMS), India \\ ${ }^{2}$ Department of Medical Biotechnology, Sikkim Manipal University, India
}

Submission: August 15, 2018; Published: October 23, 2018

*Corresponding author: Prasanta Kumar Mitra, Professor \& Head, Department of Medical Biotechnology, SMIMS, SMU, Sikkim Maniple Institute of Medical Sciences, Gangtok, Sikkim, India, Tel: +91-9434063026; Email: dr_pkmitra@rediffmail.com

\begin{abstract}
Syzygium cumini Linn. is known to possess a wide range of medicinal properties including UV absorbing property. In the present study we have examined effect of season on UV absorbing property of S. cumini L. leaves. S. cumini L. leaves were collected in summer, winter, autumn and rainy seasons. Acetone extracts of the leaves were separately prepared. Extracts were used to get absorption spectra by scanning in the wavelength range $200 \mathrm{~nm}-400 \mathrm{~nm}$ at $10 \mathrm{~nm}$ intervals. Amounts of polyphenols in the leave extracts were also checked to note correlation, if any, between poly phenol content and UV absorbing property of S. cumini L. leaves. Results showed that acetone extract of the leaves of rainy season had maximum UV absorbing property. Polyphenol content of the leaves was also high during rainy season. Acetone extract of S. cumini L. leaves of rainy season may be used as anti solar agent in preparation of sun screen lotions.
\end{abstract}

Keywords: Syzygium cumini Linn; leaves; UV absorbing property; Seasonal effect; Polyphenols; Sun screen lotion

\section{Introduction}

Numerous medicinal plants are known possessing UV absorbing property. Few of them are, Azadirachta indica, Oscimum sanctum, Calotropis gigantea L., Aloe vera, Mentha piperita, Lycopersicon esculantum and Carica papaya [1,2]. Syzygium cumini L. (family Myrtaceae) is a tropical fruit tree of great economic importance. It is a large evergreen tree up to 30 $\mathrm{m}$ height and a girth of $3.6 \mathrm{~m}$ with a bole up to $15 \mathrm{~m}$. The plant is native to Nepal, Pakistan, Bangladesh, India, and Indonesia. In India the plant is found almost everywhere. In English the plant is known as Jambul tree. In Hindi, Bengali, Punjabi, Tamil, Gujrati and Malayalam the plant is called as Jamuna, Jaam, Jammun, Naval, Gambu and Njaval respectively [3]. S. cumini L.has several medicinal properties. Leaf has anti-viral, anti-bacterial, anti-diabetic, anti-allergic, anti-DNA damage and anti-oxidant activities. Seeds exert anti-inflammatory and anti gastric ulcer activity. Fruit is anti-hyper lipidemic, possessing anti-cancer property. Bark and pulp of the plant are efficacious for diabetes [4].

Phytochemical studies showed that stem bark of S. cumini L. contains n-hentriacontane, n-octacosanol, n-triacontanol, betulinic acid, ß-sitosterol, crategolic (maslinic) acid, acid soxalic, citric acid, glycolic acids, ß-sitosterol-D-glucoside, quercetin, myricetin, astragalin kaempferol-3-o glucoside, friedelin, epi-friedelanol, eugenin and gallic acid. Leaves contain n-hepatcosane, n-nonacosane, sitosterol, betulinic acid, kaempferol 3-0-ß-D-glucuronopyranoside, ellagitannin, nilocitin, myricetin 3-0-ß-D-glucaronopyranoside and aminoacids like glycine, alanine etc. Quercetin, kaempferol, oleanolic acid, erategolic acid (maslinic acid), and myricetin flavonoids -isoquercitrin were found in the flowers of S. cumini $[5,6]$.

Recently we have noted that acetone extract of S. cumini L. leaves possesses UV absorbing property [7]. In the present study effect of season on UV absorbing property of S. cumini L. leaf was investigated. Efforts were also made to estimate number of phenolic compounds in S. cumini L. leaves in different seasons as there is a positive correlation between number of phenolic compounds in plant's leaf and its UV absorption property [8].

\section{Methodology}

\section{Plant material}

S. cumini L. leaves were collected from the medicinal plants garden of the University of North Bengal, Siliguri (26041'30.9984" N, 88027'4.5756" E, elevation, 410 ft), Dist. Darjeeling, West Bengal, India during Autumn (September November), Winter (December - February), Summer (March May) and rainy season (June - August) at about 9 am. Leaves were authenticated by the experts of the department of Botany 
of the said university. A voucher specimen was kept in the department of Medical Biotechnology, Sikkim Manipal Institute of Medical Sciences of the Sikkim Manipal University, Gangtok, Sikkim, India for future references. (Figure 1).

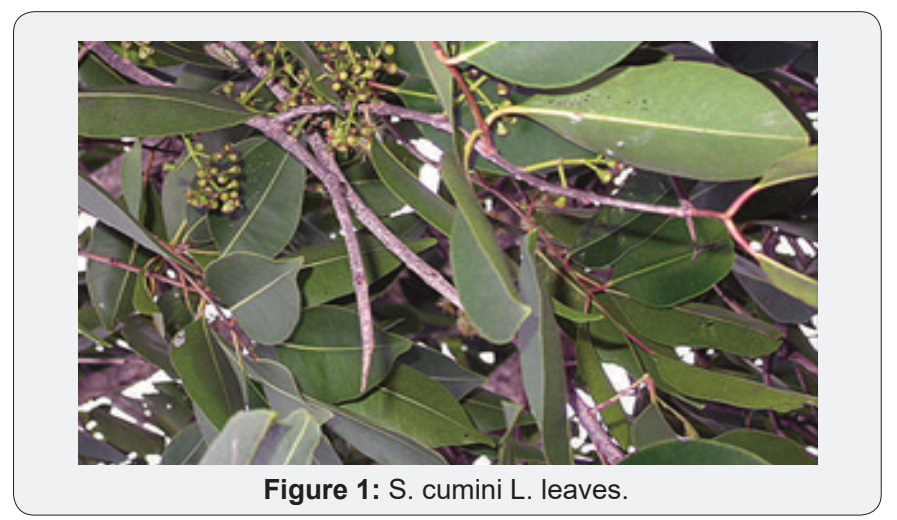

\section{Extraction of the Plant Leaves}

Collected leaves of S. cumini L. of different seasons were washed thoroughly. Leaves were then shade dried and separately powdered. The powder $(100 \mathrm{~g})$ was extracted with $500 \mathrm{ml}$ of acetone in a soxhlet apparatus at $370 \mathrm{C}$ for 15 minutes. Mixture was then filtered. Filtrate was made to dryness by using lyophilizer. Brown mass obtained.

\section{UV Ray Absorption Study}

Brown mass (10 mg) obtained from the extraction process was dissolved in $100 \mathrm{ml}$ distilled water. The solution was processed in a spectrophotometer for UV ray absorption at the range of 200-400 nm. Each experiment was done for three times and mean value calculated.

\section{Total phenols content}

$10 \mathrm{mg}$ of the brown mass obtained in extraction process was dissolved in $100 \mathrm{ml}$ distilled water and total phenols content of the solution was determined by the method of McDonald et al. [9]. Here also each experiment was done for three times and mean value calculated.

\section{Chemicals}

Chemicals required for the study were purchased from Himedia Lab, Loba Chem. Lab, India and from Merck, Germany.

\section{Statistical Analysis}

Data were analysed statistically by SPSS 20 . The statistical significance between UV absorption spectra of different extracts was evaluated with Duncan's multiple range test (DMRT). 5\% was considered to be statistically significant [10].

\section{Results and Findings}

UV absorption spectra of acetone extract of S. cumini L. leaves of rainy season is shown in (Figure 2). The extract absorbed maximum UV ray at $200 \mathrm{~nm}$ wave length which was 1.5. UV ray absorptions by the same extract at $250 \mathrm{~nm}, 300 \mathrm{~nm}$, $350 \mathrm{~nm}$ and $400 \mathrm{~nm}$ wave lengths were found $0.8,0.6,0.3$ and
0.18 respectively (Figure 3), shows UV absorption spectra of acetone extract of S. cumini L. leaves of winter. At $200 \mathrm{~nm}$ wave length the extract absorbed maximum UV rays. Value was 1.2. At $250 \mathrm{~nm}, 300 \mathrm{~nm}, 350 \mathrm{~nm}$ and $400 \mathrm{~nm}$ wave lengths the same extract of S. cumini L. leaves showed absorption $0.75,0.5,0.25$ and 0.15 respectively.

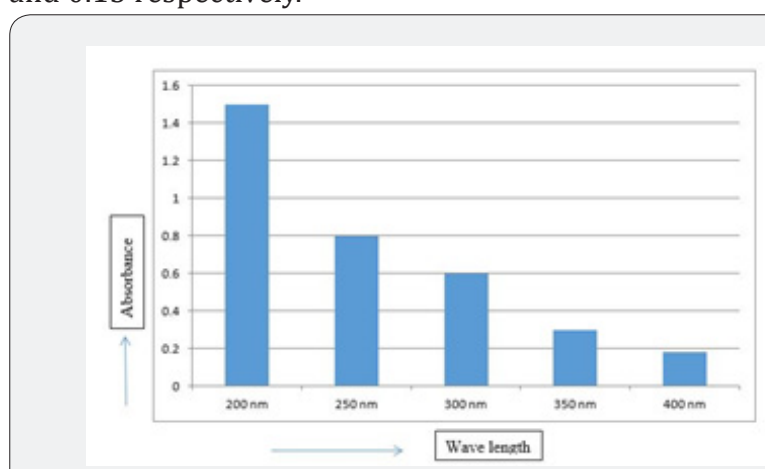

Figure 2: UV radiation absorption by the acetone extract of $S$. cumini L. leaves during rainy season.

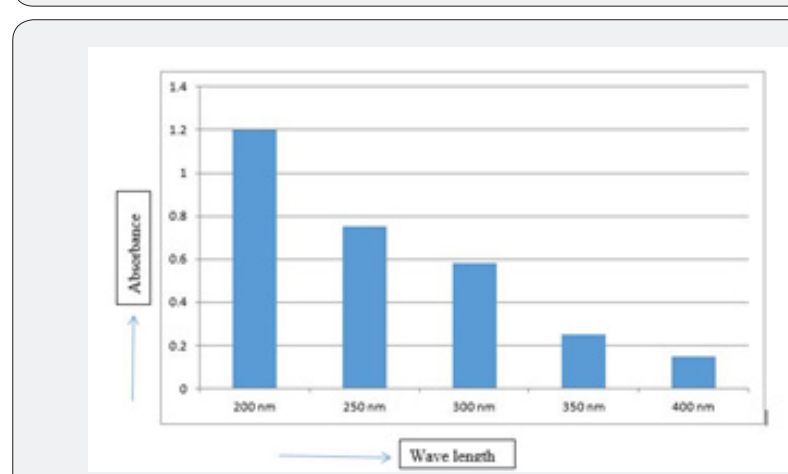

Figure 3: UV radiation absorption by the acetone extract of $\mathrm{S}$. cumini $L$. leaves during winter.

UV absorption spectra of acetone extract of S. cumini L. leaves of summer is shown in (Figure 4). The extract showed maximum UV absorption at $200 \mathrm{~nm}$. It was 1.0. UV ray absorptions by the same extract at $250 \mathrm{~nm}, 300 \mathrm{~nm}, 350 \mathrm{~nm}$ and $400 \mathrm{~nm}$ wave lengths were $0.7,0.5,0.2$ and 0.1 respectively (Figure 5), shows UV absorption spectra of acetone extract of S. cumini L. leaves of autumn. At $200 \mathrm{~nm}$ the extract absorbs maximum UV rays. It was 0.92 . At $250 \mathrm{~nm}, 300 \mathrm{~nm}, 350 \mathrm{~nm}$ and $400 \mathrm{~nm}$ wave lengths acetone extract of S. cumini L. leaves, however, showed absorption $0.67,0.48,0.15$ and 0.08 respectively.

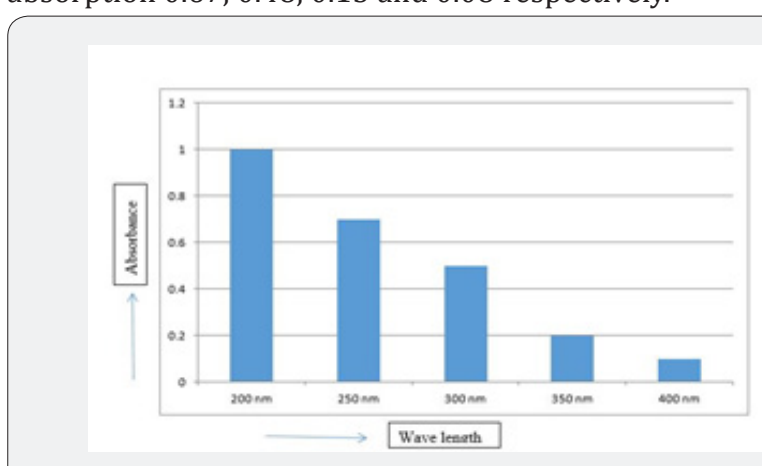

Figure 4: UV radiation absorption by the acetone extract of $S$. cumini $L$. leaves during summer. 


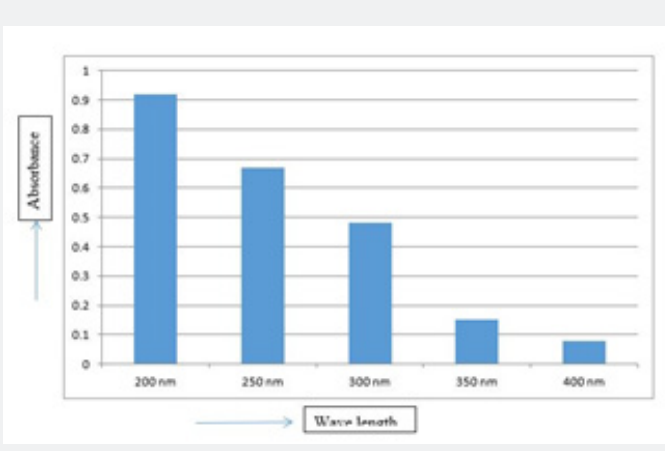

Figure 5: UV radiation absorption by the acetone extract of $S$. cumini L. leaves during autumn.

Effect of season on amount of phenolic compounds in S. cumini L. leaves is shown in (Figure 6). S. cumini L. leaves collected during rainy season had $63.0 \mathrm{mg}$ phenolic compounds in $1 \mathrm{~g}$ dry wt of the leaves whereas S. cumini L. leaves collected during winter, summer and autumn had 40.0, 35.0, $30.0 \mathrm{mg}$ of phenolic compounds per g dry wt of the leaves respectively (Figure 7).

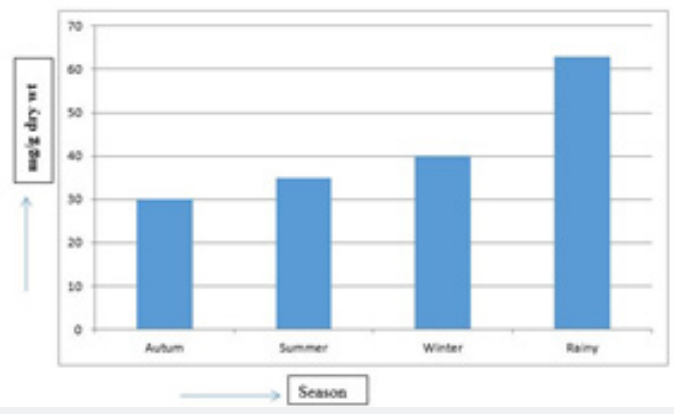

Figure 6: Number of phenolic compounds in S. cumini L. leaves: Effect of season.

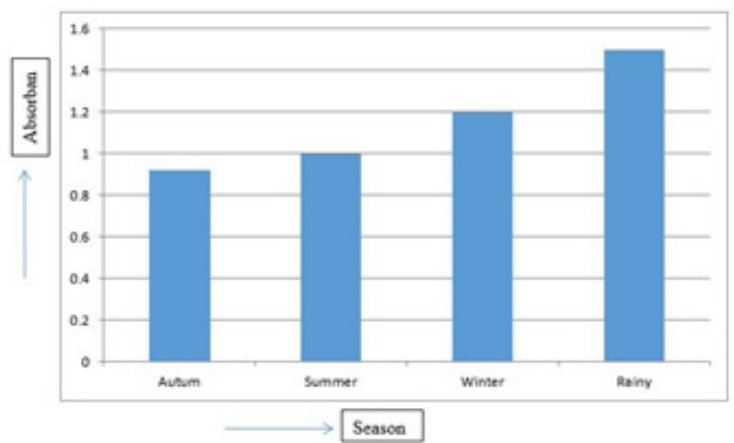

Figure 7: Seasonal effect on UV radiation absorption by the acetone extract of S. cumini L. leaves.

\section{Discussion}

Solar UV-radiation is required for cutaneous synthesis of vitamin D. This covers almost $90 \%$ of the vitamin D-requirements of the human body. But the solar UV radiation has adverse effects also. One of the important environmental risk factors for development of non-melanoma skin cancer is solar UV-radiation.
Besides, solar UV-radiation has lot of detrimental effects. One example is photosensitivity reactions to ingested drugs.

Excessive exposure to UV carries profound health risks including pigmentary changes, atrophy, wrinkling etc. [11-13]. Efforts are therefore made to invent sources through which solar / artificial UV rays can be absorbed. In this context work has been extended even in the field of medicinal plants [1,2]. In the present study we have confirmed UV absorbing property of acetone extract of S. cumini L. leaves. The plant leaves collected during winter, summer, autumn and rainy seasons showed UV absorbing property in all wave lengths of UV region, but maximum absorption was found in $200 \mathrm{~nm}$ wave length (Figures 2-5).

When compared the UV absorbing property of acetone extract of S. cumini L. leaves of different seasons, we have noticed that S. cumini L. leaves collected during rainy season had maximum UV absorbing property in $200 \mathrm{~nm}$ followed by S. cumini L. leaves collected during winter, summer and autumn (Figure 7). This is probably the influence of climate of different seasons on secondary metabolites in medicinal plants. Several authors demonstrated that season can change amount of bio active compounds in different parts of the plants [14-23].

In the present study we also estimated number of phenolic compounds in S. cumini L. leaves of different seasons. Results showed that S. cumini L. leaves of rainy season had maximum number of phenolic compounds (Figure 6). This high number of phenolic compounds may have correlation with maximum UV absorbing property of S. cumini L. leaves of rainy season. Ebrahimzadeh et al. also showed a positive correlation between number of phenolic compounds in plant's leaf and its UV absorption property [8]. UV absorption property of S. cumini L. leaves may be due to presence of other compound(s) apart from phenolics. Presently work is now going on in this direction.

\section{Conclusion}

Acetone extract of S. cumini L. leaves of rainy season contains high number of phenolic compounds and has maximum UV radiation absorbing property.

\section{Recommendation}

In preparation of sun screen lotion and other UV guard materials acetone extract of S. cumini L. leaves of rainy season may be used.

\section{Acknowledgement}

We gratefully acknowledge the cooperation of taxonomists of the department of Botany, University of North Bengal, Siliguri, Dist. Darjeeling, West Bengal for identification of S. cumini L leaves.

\section{Conflict of Interest}

$\mathrm{Nil}$ 


\section{References}

1. Gharge VG, Yadav A (2018) Study of Methanolic Extract of Leaves Calotropis gigantean (L.) As an Anti-Solar. Adv Complement Alt Med 1(4): 1-3.

2. Gupta Dipali (2013) Absorbing Properties of Some Plant Derived Extracts. Research Journal of Chemical and Environmental Sciences 1(2): 34-36

3. Jadhav VM, Kamble SS, Kadam VJ (2009) Herbal Medicine: Syzygium Cumini: A Review. Journal of Pharmacy Research 2(8) :1212-1219.

4. Chaudhary B, Mukhopadhyay K (2012) Syzygium cumini (L.) skeels: A potential Source of Nutraceuticals. International Journal of Pharmacy and Biological Sciences 2(1): 46-53.

5. Bhargava KK, Dayar R, Seshadri T R (1974) Chemical Components of Eugenia Jambolana Stem Bark. Current Sci 43(20) :645- 646.

6. Gupta GS, Sharma DP (1974) Triterpenoid and Other Constituents of Eugenia Jambolana Leaves. Phytochemistry 13(9) :2013-2014.

7. Mitra Prasenjit, Mitra Prasanta Kumar, Ghosh Tanaya (2018) UV Absorption Property of Syzygium cumini L. Leaves. Acta Scientific Pharmaceutical Sciences 2(9): 69-73.

8. Ebrahimzadeh Mohammad Ali, Enayatifard Reza, Khalili Masoumeha, Ghaffarloo Mahdieh, Saeedi Majid, et al. (2014) Correlation between Sun Protection Factor and Antioxidant Activity, Phenol and Flavonoid Contents of some Medicinal Plants. Iranian Journal of Pharmaceutical Research 13 (3): 1041-1047.

9. McDonald S, Prenzler PD, Autolovich M, Robards K (2001) Phenolic Content and Antioxidant Activity of Olive Extracts. Food Chemistry 73(1): 73-84.

10. Bliss CI (1967) Statistics in Biology, Statistical Methods for Research in the Natural Sciences (Vol. 1). McGraw Hill Book Company, NY, pp. 558.

11. D'Orazio John, Jarrett Stuart, Amaro-Ortiz Alexandra, Scott Timothy (2013) UV Radiation and the Skin. Int J Mol Sci 14(6): 12222-12248.

12. Elwood JM, Jopson J (1997) Melanoma and Sun Exposure: An Overview of published Studies. Int J Cancer 73(2): 198203.
13. MacKie RM (2000) Effects of Ultraviolet Radiation on Human Health. Radiation Protection Dosimetry 91(1-3):15-18.

14. Fluck H, Pharm M (1955) The influence of climate on the active principles in medicinal plants. J Pharm Pharmacol 7(6): 361-383.

15. Gupta PL (1977) Variation in morphological characters and active principle constituents of E. prostrata Linn. under different seasonal and soil conditions. JRIM 12(1): 80-84.

16. Schultz JC, Nothnagle PJ, Baldwin IT (1982) Seasonal and individual variation in leaf quality of two northern hardwoods tree species. American Journal of Botany 69(5): 753-759.

17. Mauffette Y, Oechel WC (1989) Seasonal variation in leaf chemistry of the coast liveoak Quercus agrifolia and implications for the California oak moth Phryganidia californica. Oecologia 79(4): 439-445.

18. Bahmanzadegan Atefeh, Rowshan Vahid, Zareian Faraneh, Alizadeh Reza, Bahmanzadegan Mohammad (2015) Seasonal Variation in Volatile Oil, Polyphenol Content and Antioxidan Activity in Extract of Laurus nobilis Grown in Iran. Journal of Pharmacy and Pharmacology 3: 223-231.

19. Mitra Prasanta Kumar (2014) In vitro antibacterial activity of leaves of Amaranthus spinosus L.: Seasonal variation. World Journal of Pharmaceutical Sciences 2(12): 1702-1706.

20. Ghosh Tanaya, Mitra Prasenjit, Jha Dilip Kumar, Mitra Prasanta Kumar (2015) A study on body weight loss in rats by the leaves of Abrus precatorius Linnaeus: Effect of season. International Journal of Pharmacy \& Therapeutics 5(2): 52-57.

21. Mitra Prasenjit, Ghosh Tanaya, Mitra Prasanta Kumar (2016) Seasonal variation in anti-ulcerogenic activity of ageratum conyzoides l. leaves. International Journal of Biopharmaceutics 7(2): 63 - 68.

22. Mitra Prasanta Kumar, Ghosh Tanaya, Mitra Prasenjit (2016) In vitro anti thiamine effect of murrya koenigii (linn.) spreng wettst leaves: effect of season. International Journal of Biopharmaceutics 7(2): 69 72.

23. Mitra Prasenjit, Ghosh Tanaya, Mitra Prasanta Kumar (2017) Effect of Season on In vitro Anti-Oxidant Activity of Aageratum conyzoides L. Leaves. SMU Medical Journal 4(2): 222-233.

\section{Your next submission with Juniper Publishers will reach you the below assets}

- Quality Editorial service

- Swift Peer Review

- Reprints availability

- E-prints Service

- Manuscript Podcast for convenient understanding

- Global attainment for your research

- Manuscript accessibility in different formats

( Pdf, E-pub, Full Text, Audio)

- Unceasing customer service

Track the below URL for one-step submission https://juniperpublishers.com/online-submission.php 